\title{
Malignant transformation of dental material-induced oral lichenoid contact reaction: A case report describing outcomes after amalgam removal
}

Dental materyal ilişkili oral likenoid kontakt reaksiyonun malign dönüşümü: Amalgam çıkarımı sonrası sonuçların ortaya konulduğu bir olgu

\section{Ahu Yorulmaz ${ }^{1}$, Başak Yalçın ${ }^{1}$, Ayşe Boyvat ${ }^{2}$, Ömür Ataoğlu ${ }^{3}$, Önder Bozdoğan ${ }^{4}$}

\section{Abstract}

Oral lichen planus (OLP) is a chronic immune-mediated dermatosis of unknown origin. Considered as one of the most common diseases of the oral mucosa, OLP has been subject of intense interest since its first identification as a premalignant condition. Oral lichenoid contact reactions (OLCRs) are distinct analogs of OLP lesions, in that they are nearly indistinguishable from OLP both clinically and histologically. There is an on-going debate about whether the underlying condition causing OLP-induced malignant oral squamous cell carcinoma is OLP or OLCR. Even currently, a considerable number of patients with OLCR are diagnosed and managed as OLP without searching for specific causative agents. Dental restorative materials are one of the most common inducers of OLCR. Here, we describe a case with dental material-induced OLCR, who had previously undergone marginal mandibulectomy and neck dissection with a diagnosis of invasive well differentiated squamous cell carcinoma associated with OLP. We emphasize the need for investigation of possible etiological factors in every case of OLP or OLCR, as a basal patch test may completely change the course of the disease.

Keywords: oral lichen planus, oral lichenoid contact reactions, oral squamous cell carcinoma, dental restorative materials, patch test

\section{Öz}

Oral liken planus (OLP), etiyolojisi henüz tüm yönleriyle aydınlatılamamış kronik immün aracılı bir dermatozdur. Oral mukozanın en sık hastalıkları arasında kabul edilen OLP, premalign bir durum olarak tanımlanmasından bu yana çok daha fazla ilgi gören bir hastalık haline gelmiştir. Oral likenoid kontakt reaksiyonlar (OLKR), OLP'den gerek klinik, gerekse histopatolojik olarak neredeyse ayırt edilemez, bu nedenle OLP lezyonlarının analoğu olarak görülürler. Hali hazırda, OLP ilişkili malign oral skuamöz hücreli karsinomaya neden olan tetikleyici hastalığın, OLP ya da OLKR'den hangisinin olduğu konusunda süregelen tartışmalar vardır. Dahası, günümüzde halen kayda değer sayıda OLKR tanılı hasta, altta yatan spesifik etiyolojiler araştırılmadan OLP olarak kabul edilmekte ve tedavi görmektedir. Dental restoratif materyaller OLKR'in en önemli tetikleyicileri arasındadır. Biz de burada, dental restoratif materyal ilişkili OLKR tanısı koyduğumuz ve bize başvurmadan önce OLP'nin neden olduğu oral mukozanın iyi diferansiye malign oral skuamöz hücreli karsinoma tanısıyla marjinal mandibulektomi ve boyun diseksiyonu uygulanan bir olguyu sunmak istiyoruz. Biz, her OLP ve OLKR olgusunda olası etiyolojik faktörlerin aydınlatılması gerektiği kanaatindeyiz, çünkü yapılacak bir bazal yama testi hastalığın klinik seyrini tamamıyla değiştirebilir.

Anahtar kelimeler: oral liken planus, oral likenoid kontakt reaksiyonlar, oral skuamöz hücreli karsinom, dental restoratif materyaller, yama testi

\section{${ }^{1}$ Ankara Numune Research and Education Hospital, Department of Dermatology, Ankara, Turkey \\ ${ }^{2}$ Ankara University School of Medicine, Department of Dermatology, Ankara, Turkey ${ }^{3}$ Private and Teaching Practice of Pathology, Ankara, Turkey \\ ${ }^{4}$ Ankara Numune Research and Education Hospital, Department of Pathology, Ankara, Turkey}

Informed Consent: The the written consent was received from the patient who was presented in this study.

Hasta Onamı: Calıșmada sunulan hastadan yazılı onam alınmıştır.

Conflict of Interest: No conflict of interest was declared by the authors.

Çıkar Çatışması: Yazarlar çıkar çatışması bildirmemişlerdir.

Financial Disclosure: The authors declared that this case has received no financial support.

Finansal Destek: Yazarlar bu olgu için finansal destek almadıklarını beyan etmişlerdir.

Geliş Tarihi / Received: 21.12.2017

Kabul Tarihi / Accepted: 23.01.2018

Yayın Tarihi / Published: 20.02.2018

Sorumlu yazar / Corresponding author Ahu Yorulmaz

Adres/Address: Department of Dermatology,

Ankara Numune Research and Education

Hospital, Samanpazari, Altindag, Ankara,

Turkey.

Tel: +90505938 1709

e-posta: ahuyor@gmail.com

Copyright $(\subset$ ACEM 


\section{Introduction}

Lichen planus is a common chronic inflammatory dermatosis affecting skin, mucous membranes, and nails [1]. Oral lichen planus (OLP), which is one of the most common diseases of the oral mucosa, generally occurs in middle-aged women [2, 3]. Oral lichenoid contact reactions (OLCRs), also called as oral lichenoid lesions (OLLs), represent a spectrum of lesions, in which findings are indistinguishable from OLP both clinically and histologically. The main difference between these conditions is the presence of an identifiable initiating factor in OLCR [3-5]. Moreover, although both OLP and OLCR have been assumed to be potentially malignant, it has been suggested that the one which has the premalignant nature is OLCR [3, 5-7].

Here, we report a case with OLCR, who had undergone marginal mandibulectomy and neck dissection with a histopathology report of invasive well-differentiated oral squamous cell carcinoma (OSCC). She had been diagnosed and managed as OLP and several years after we have performed a patch test with dental screening series, which have confirmed the contact allergy to dental restorative materials.

\section{Case report}

A 56-year-old woman came to our outpatient clinic with several years' history of an intractable oral ulcer. Her medical history revealed that she had been diagnosed with erosive OLP several years ago and treated for many times without improvement. Two years ago, she was diagnosed as having invasive well differentiated OSCC associated with OLP and finally undergone marginal mandibulectomy and neck dissection. On the other hand, after the operation the oral ulcer recurred. There was no family and past history of any other diseases, medication. In addition, she did not have a history of smoking. On oral examination, we observed a round ulcer with clearly defined margins, measuring $1 \times 1 \mathrm{~cm}$ in diameter on right posterior buccal region (Figure 1). We also observed dental fillings adjacent to the ulcer. The patient did not want any other invasive procedure including oral mucosa biopsy. The pathological specimens of the patient, which were readily available were reexamined and reevaluated in our institute. Examination of the specimens revealed that it was consistent with invasive OSCC (Figure 2). We questioned the diagnosis of OLP and regarded OLCR as the primary disease. Thus, we established a patch test with dental screening series. According to 48,72 and 96 hour readings, positive patch test reactions to sodium tetrachloropalladate hydrate $(+3)$, nickel sulfate hexahydrate $(+3)$ and palladium chloride $(+2)$ were observed. Based on history and clinical findings, we made a diagnosis of dental material-induced oral lichenoid contact reaction. The patient was referred to a dentist for removal of the dental fillings. We prescribed the patient oral acitretin $20 \mathrm{mg}$ daily. After acitretin treatment and replacement of dental fillings with nonallergen containing products, a dramatic resolution of lesions was observed within months (Figure 3). The patient was taken under follow-up with oral acitretin $20 \mathrm{mg}$ daily. Currently, the patient is disease-free at six months follow up. Written consent was taken from the patient.

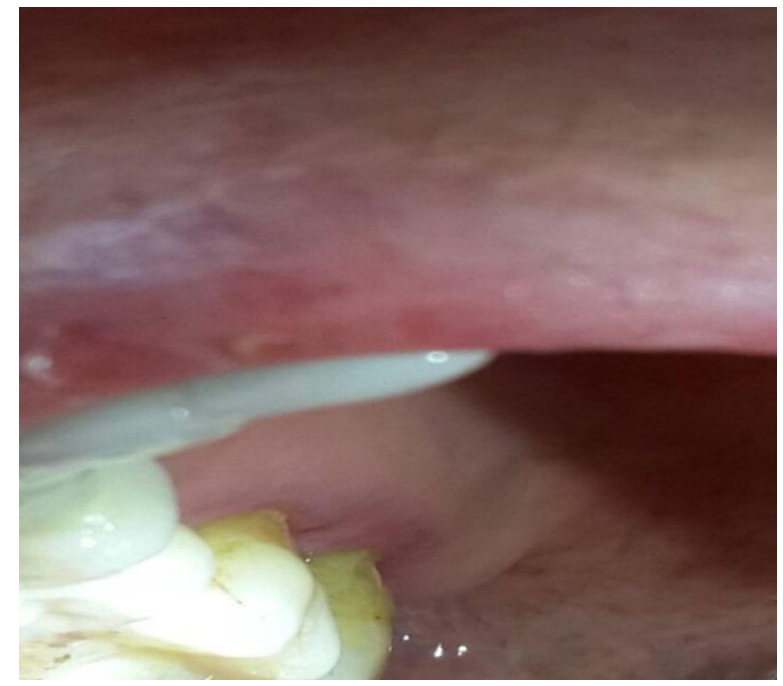

Figure 1: Ulcer on right posterior buccal region

A
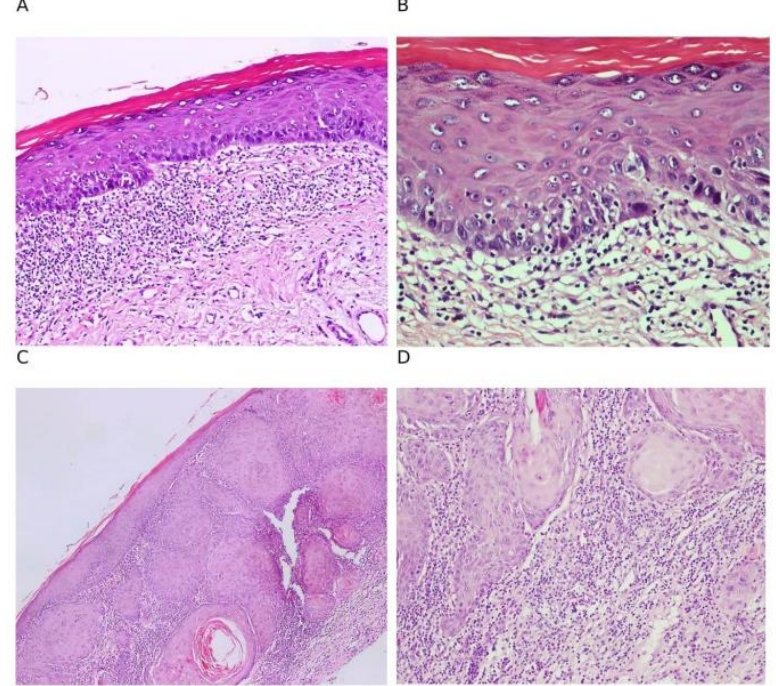

Figure 2: Lichenoid infiltration and basal cell atypia in oral mucosa ( $a$ and $b$ ). Invasive well-differentiated squamous cell carcinoma (c and d) with significant inflammatory reaction around tumor islands (d) (a and d: $\times 100, \mathrm{c}: \times 40, \mathrm{~b}: \times 200)$

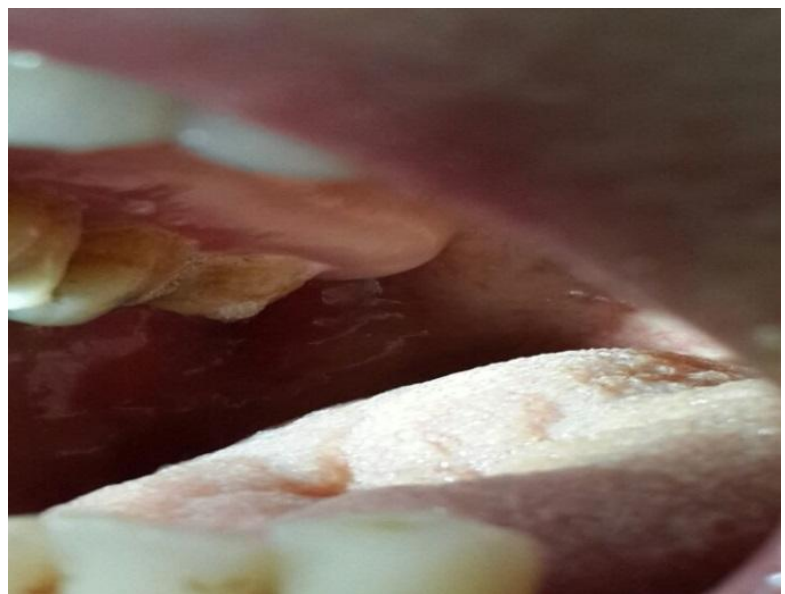

Figure 3: Dramatic resolution of the ulcer after removal of dental material (3rd month of acitretin treatment)

\section{Discussion}

OLCR constitutes a group of lesions mediated by delayed-type hypersensitivity response. Dental restorative materials, particularly mercury-containing amalgam, are one of the most common causative factors for OLCR. Even several months to years after contact with mercury, a cell-mediated immune response is initiated in susceptible individuals. Although the exact pathophysiological mechanism of OLCR is still obscure, it has been suggested that patient's human leukocyte 
antigen type is a fundamental determinant in shaping the delayed type immune response, which is carried out by both CD8+ cytotoxic and CD4+ helper T cells [3, 4, 6, 8].

The clinical presentation of OLCR is typical with lesions identical to lesions of OLP. White reticular papules and patches, white plaque-like appearance, erythematous erosions and ulcerations may be found both in OLP and OLCR. On the other hand, while OLP generally affects multiple sites in the oral cavity bilaterally and symmetrically, OLCR lesions, which are usually erosive in nature, tend to be unilateral and localized to the site of contact with dental material [3-5, 8]. Although there are several reports in the literature describing malignant potential of OLP, it has been suggested that only OLCR, but not OLP, has the malignant potential and if an OLP like lesion is associated with malignancy, it should not be termed as OLP, as it is indeed OLLs, which includes OLCR [6, 7, 9-13]. Accordingly, some authors use the term OLL, when the lesion has an attributable causative factor and a malignancy potential $[5,6]$.

Patch test is utmost important in the diagnosis of OLCR. A lichenoid lesion with a topographical relationship with dental restorative materials implies a diagnosis of OLCR and a patch test with dental screening series ascertains contact allergy to amalgam-related allergens. Although the patch test has disadvantages such as a relatively long period required for testing and the risk of sensitization, in the setting of a unilateral recalcitrant lesion, which has a typical topographic association with dental restorations, patch testing is a must to be considered $[3,4,8]$. In patients with positive results, replacement of dental restorations induces significant improvement in lesions $[3,4,8$, $14,15]$.

Our case represents an exceptional case of malignant transformation of dental material-induced OLCR. She had been diagnosed and managed as treatment resistant OLP for several years without administration of a prerequisite, which was a basic patch testing with dental screening series in this particular instance. The fact that she had undergone marginal mandibulectomy and neck dissection was another drawback. In addition, patch test results were also remarkable in our patient. It is known that the most common culprit allergen in OLCR is mercury [4, 8, 15-17]. However, our patient did not have a positive reaction to mercury, instead, a strong positive reaction was observed to palladium chloride, and extreme reactions were elicited by sodium tetrachloropalladate hydrate and nickel sulfate hexahydrate, which are other dental allergens. We highlight the importance of patch testing, which is indeed practical and when outcomes of the patients are taken into account has inestimable results. On the other hand, we recognize the truth that malignancy is a multifactorial process. We can't assume that the single causative factor in our patient was OLCR. We suggest that OLCR is the triggering component in the tumorigenesis. Case reports like ours would contribute to a better understanding of the importance of the patch test and consequences of dental materials induced contact reactions.

\section{References}

1. Lehman JS, Tollefson MM, Gibson LE. Lichen planus. Int J Dermatol. 2009;48:682-94.

2. Sugerman PB, Savage NW. Oral lichen planus: Causes, diagnosis and management. Aust Dent J. 2002;47:290-7.

3. Schlosser BJ. Lichen planus and lichenoid reactions of the oral mucosa. Dermatol Ther. 2010;23:251-67.

4. Suter VG, Warnakulasuriya $\mathrm{S}$. The role of patch testing in the management of oral lichenoid reactions. J Oral Pathol Med. 2016;45:48-57.

5. Carrozzo M, Thorpe R. Oral lichen planus: A review. Minerva Stomatol. 2009;58:519-37.

6. Shirasuna K. Oral lichen planus: Malignant potential and diagnosis. Oral Sci Int. 2014;11:1-7.
7. Fitzpatrick SG, Hirsch SA, Gordon SC. The malignant transformation of oral lichen planus and oral lichenoid lesions: A systematic review. J Am Dent Assoc. 2014;145:45-56.

8. McParland $\mathrm{H}$, Warnakulasuriya S. Oral lichenoid contact lesions to mercury and dental amalgam - A review. J Biomed Biotechnol. 2012;2012:589569.

9. Mattsson U, Jontell M, Holmstrup P. Oral lichen planus and malignant transformation: Is a recall of patients justified? Crit Rev Oral Biol Med. 2002;13:390-6.

10. Georgakopoulou EA, Achtari MD, Achtaris M, Foukas PG, Kotsinas A. Oral lichen planus as a preneoplastic inflammatory model. J Biomed Biotechnol. 2012;2012:759626

11. Gandara-Rey JM, Freitas MD, Vila PG, Carrion AB, SuarezPenaranda JM, Garcia AG. Malignant transformation of oral lichen planus in lingual location: Report of a case. Oral Oncol Extra. 2004;40:1-4.

12. Braun KA, Massa L. Oral lichen planus with malignant transformation to invasive squamous cell carcinoma. Cutis. 2015;96:E12-14

13. Kissi L, Benyahy I. Hyper keratotic oral lichen planus and malignant transformation. Odontostomatol Trop. 2015;38:56-62.

14. Mårell L, Tillberg A, Widman L, Bergdahl J, Berglund A. Regression of oral lichenoid lesions after replacement of dental restorations. J Oral Rehabil. 2014;41:381-391.

15. Issa Y, Duxbury AJ, Macfarlane TV, Brunton PA. Oral lichenoid lesions related to dental restorative materials. $\mathrm{Br}$ Dent $\mathrm{J}$. 2005;198:361-6.

16. Ditrichova D, Kapralova S, Tichy M, Ticha V, Dobesova J, Justova E, et al. Oral lichenoid lesions and allergy to dental materials. Biomed Pap Med Fac Univ Palacky Olomouc Czech Repub. 2007;151:333-9.

17. Lynch M, Ryan A, Galvin S, Flint S, Healy CM, O'Rourke N, et al. Patch testing in oral lichenoid lesions of uncertain etiology. Dermatitis. 2015;26:89-93. 